\title{
Serum levels of tau protein increase according to the severity of the injury in DAI rat model [version 1; peer review: 2
}

\section{approved, 1 approved with reservations]}

\section{Keisuke Tomita (D), Taka-aki Nakada (D), Taku Oshima, Rui Kawaguchi, Shigeto Oda}

Department of Emergency and Critical Care Medicine, Chiba University Graduate School of Medicine, 1-8-1 Inohana, Chuo, Chiba, 260-8677, Japan

V1 First published: 20 Jan 2020, 9:29

https://doi.org/10.12688/f1000research.21132.1

Latest published: 20 Jan 2020, 9:29

https://doi.org/10.12688/f1000research.21132.1

\section{Abstract}

Traumatic brain injury (TBI) in the form of diffuse axonal injury (DAI) is difficult to diagnose in the early phase of the injury. Early diagnosis of DAI may provide opportunity for developing treatment and management strategies. Tau protein has been demonstrated to increase in the early phase of TBI with high diagnostic accuracy in patients with DAI. We tested the biological plausibility of tau protein using a rat DAI model by evaluating the association between serum tau levels and the severity of brain injury. DAI was induced in animals using the Marmarou model. After a survival of 60 minutes, rats were anesthetized and sacrificed after obtaining blood samples $(5 \mathrm{ml})$ from the heart. Eighteen rats were employed in the present study and were randomly subjected to sham-operated control $(n=4)$, mild DAI $(n=7)$, and severe DAI $(n=7)$. Of seven severe DAI rats, two rats that had focal injury caused by skull fracture were excluded in the measurement of tau protein level. The serum levels of tau protein in the rat DAI model were found to increase significantly and consistently according to the severity of the injury. Rats with DAI showed significantly higher serum levels of tau protein compared to sham rats; the severe DAI rats had higher levels of tau than moderate DAI and sham rats (sham vs. mild, $P=0.02$; mild vs. severe, $P=0.02$ ). In conclusion, serum tau protein levels may be useful as a biomarker for diagnosing and estimating the severity of DAI in the early phase.

\section{Keywords}

serum tau protein, diffuse axonal injury, traumatic brain injury, biomarker

\section{Open Peer Review \\ Approval Status ? 12 23 \\ version 1

$?$ $\checkmark$ $\checkmark$ \\ 20 Jan 2020 \\ 1. Vassilis E Koliatsos, Johns Hopkins University, Baltimore, USA \\ 2. Mieszko Olczak, Medical University of Warsaw, Warsaw, Poland \\ 3. Amanda Heslegrave ID, University College London, London, UK}

Any reports and responses or comments on the article can be found at the end of the article. 
Corresponding author: Taka-aki Nakada (taka.nakada@nifty.com)

Author roles: Tomita K: Conceptualization, Data Curation, Formal Analysis, Funding Acquisition, Investigation, Methodology, Project Administration, Validation, Visualization, Writing - Original Draft Preparation, Writing - Review \& Editing; Nakada Ta: Conceptualization, Data Curation, Formal Analysis, Investigation, Methodology, Project Administration, Supervision, Writing - Review \& Editing; Oshima T: Formal Analysis, Methodology, Supervision, Writing - Review \& Editing; Kawaguchi R: Writing - Original Draft Preparation, Writing Review \& Editing; Oda S: Conceptualization, Writing - Review \& Editing

Competing interests: No competing interests were disclosed.

Grant information: K.T. was supported by Japan Society for the Promotion of Science [JP15K20334].

The funders had no role in study design, data collection and analysis, decision to publish, or preparation of the manuscript.

Copyright: @ 2020 Tomita K et al. This is an open access article distributed under the terms of the Creative Commons Attribution License , which permits unrestricted use, distribution, and reproduction in any medium, provided the original work is properly cited.

How to cite this article: Tomita $\mathrm{K}$, Nakada Ta, Oshima $\mathrm{T}$ et al. Serum levels of tau protein increase according to the severity of the injury in DAI rat model [version 1; peer review: 2 approved, 1 approved with reservations] F1000Research 2020, 9:29

https://doi.org/10.12688/f1000research.21132.1

First published: 20 Jan 2020, 9:29 https://doi.org/10.12688/f1000research.21132.1 


\section{Introduction}

Traumatic brain injury (TBI) in the form of diffuse axonal injury (DAI) is difficult to diagnose with computed tomography (CT) scans, due to the minimal effect on the anatomical structure of the brain in the early phase of the injury. However, DAI is frequently associated with poor clinical outcome, due to the extensive shear disruption of the axons by rotational or acceleration forces of the head ${ }^{1,2}$.

Early diagnosis of DAI may contribute to developing treatment and management methods. Apart from imaging diagnostic techniques, biomarkers may be useful in diagnosing DAI and predicting its severity. We focused on tau, a protein which composes important structural elements in the axonal cytoskeleton $^{3}$. Tau protein has been demonstrated to increase in the early phase of TBI with high diagnostic accuracy in patients with $\mathrm{DAI}^{4}$. In addition, blood tau protein level has been reported to increase in concussion and chronic traumatic encephalopathy ${ }^{5,6}$, and it has also been reported that there is an association with severity. However, the same effect has not been confirmed in DAI. Therefore, we tested the biological plausibility of tau protein using a rat DAI model by evaluating the association between serum tau levels and the severity of brain injury.

\section{Methods}

\section{Ethical statement}

The animal study protocol and procedures were reviewed and approved by the Animal Research Committee of Chiba University (approval number 26-341) following the Guidelines for Proper Conduct of Animal Experiments (Science Council of Japan). All procedures used in this study were optimized to minimize animal suffering and distress by carefully following the procedures and monitoring the effectiveness of the analgesics.

\section{Animals}

Male Sprague-Dawley rats (13-14 weeks old, weighing 330-380g) were obtained from CLEA Japan, Inc. A total of eighteen rats were used for this study and were allocated to experimental groups using simple randomization. Each rat was housed one per cage; $(270 \times 440 \times 187 \mathrm{~mm}$; KN-601, Natsume Seisakusyo Co., Ltd., Japan) and standard corn cob cage bedding was used. The rats were kept under $12 \mathrm{~h}$ light and dark conditions with water and food ad libitum in the animal room at Chiba University, Japan. The diet consisted of standard laboratory feed (CLEA Rodent Diet CA-1, CLEA Japan, Inc.). Temperature $\left(20-24^{\circ} \mathrm{C}\right)$ and humidity $(50-55 \%)$ were also controlled. All rats were checked daily for general physical and health appearance, bedding/water bottle circumstances and any signs of distress.

\section{DAl model}

Each rat was selected randomly from the cage, and the procedures were performed one by one. DAI was induced in animals using the Marmarou model in the laboratory during light conditions ${ }^{7}$. The Marmarou model is recognized as one of the most commonly used to create DAI in rats. It is inexpensive, easy to perform and capable of producing graded DAI that closely mimics that seen in human TBI. Rats were anesthetized by intraperitoneal injections of medetomidine hydrochloride $(0.375 \mathrm{mg} / \mathrm{kg})$, midazolam $(2 \mathrm{mg} / \mathrm{kg})$ and butorphanol tartrate $(2.5 \mathrm{mg} / \mathrm{kg})^{8}$. Then, the skull of the rat was exposed with a midline incision to adhere a helmet, a $10 \mathrm{~mm}$ diameter stainless steel disk with a thickness of $3 \mathrm{~mm}$, at the midline between the coronal and the lambdoid suture. Subsequently, rats were fixed on a foam bed in prone position. A weight $(450 \mathrm{~g})$ impounder was allowed to fall freely through a Plexiglas guide tube from a predetermined height (severe group $2 \mathrm{~m}$; mild group $1 \mathrm{~m}$ ) to provide an impact to the helmet. After the impact, the stainless steel disk was removed and the incision was sutured. Shaminjured rats underwent the same surgical procedure but were not subjected to injury. Rats were housed and warmed at $37.0^{\circ} \mathrm{C}$ using a heating pad. After a survival time of 60 minutes, DAI and control rats were anesthetized by intraperitoneal injections of medetomidine hydrochloride $(0.375 \mathrm{mg} / \mathrm{kg})$, midazolam $(2 \mathrm{mg} / \mathrm{kg})$ and butorphanol tartrate $(2.5 \mathrm{mg} / \mathrm{kg})$ and sacrificed by the method of cervical dislocation after obtaining blood samples $(5 \mathrm{ml})$ by puncturing the heart with a $23 \mathrm{G}$ needle. Serum was centrifuged at $1000 \mathrm{rpm}$ for $20 \mathrm{~min}$ and stored at $-80^{\circ} \mathrm{C}$ until analysis according to the instructions of enzyme linked-immunosorbent assay (ELISA) kit.

\section{Measurements}

Serum levels of tau protein were measured using a commercially available kit based on the principle of the sandwich ELISA (Cat. no. LS-F23602, LSBio, WA) according to the manufacturer's instructions. Absorbance readings at wavelength $450 \mathrm{~nm}$ were performed on the automated plate reader SpectraMax ${ }^{\circledR}$ M5e with SoftMax Pro Ver. 5.2. Measurements were performed in duplicates.

\section{Statistical analysis}

In the present study, serum tau protein levels of tau were compared between control and mild injury and between mild and severe injury using Mann-Whitney's U-test. Since there was no data available to calculate the sample size from previous studies, two cases were first tested in each group. From these results, the estimated level of serum tau protein was $1300 \pm 200$ $\mathrm{pg} / \mathrm{mL}$ in the severe DAI group. Furthermore, we also estimated tau protein levels at $900 \mathrm{pg} / \mathrm{mL}$ in the mild DAI group and $500 \mathrm{pg} / \mathrm{mL}$ in the sham-injured group. In order to achieve the level of statistical significance of 0.05 with a power of $80 \%$, data for four rats in each group were needed. A previous study had reported that death or skull fracture occurred in about $40 \%$ of the severe DAI group ${ }^{7}$. Therefore, we planned to use seven rats for the experiment in the severe DAI group. In addition, seven rats were used in the mild group in case of any adverse events occurring. All statistical analysis was performed with the GraphPad Prism 7 (GraphPad Software, San Diego, CA, USA).

\section{Results}

Eighteen rats were employed in the present study and were randomly subjected to sham-operated control $(n=4)$, mild DAI $(n=7)$, and severe DAI $(n=7)$. The mean weight \pm standard deviation $(\mathrm{SD})$ and age $\pm \mathrm{SD}$ in each group was 
$360.0 \pm 8.2 \mathrm{~g}, 365.7 \pm 13.9 \mathrm{~g}$ and $360.6 \pm 13.7 \mathrm{~g}$, and $94.3 \pm 2.6$ postnatal days, $93.1 \pm 1.1$ postnatal days and $93.2 \pm 1.3$ postnatal days, respectively ${ }^{9}$. Of seven severe DAI rats, two rats that had focal injury caused by skull fracture were excluded in the measurement of tau protein level. The serum levels of tau protein in the rat DAI model were found to increase significantly and consistently according to the severity of the injury (Figure 1).

\section{Discussion}

In our study, the serum tau protein levels in the rat DAI model were found to increase significantly and consistently according to the severity of the injury.

The potential biomarkers of DAI such as S-100 calcium-binding protein $\mathrm{B}$, neuron specific enolase, neuron filament, etc., have been evaluated for usefulness for diagnosis and prognostication, with limited success to date ${ }^{10-12}$. Tau protein is a microtubuleassociated protein and has highly specific expression in neuronal axons ${ }^{3}$. In a previous animal study, serum tau levels were

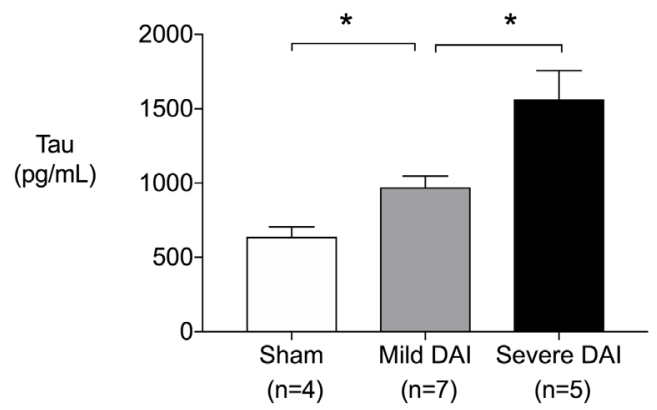

Figure 1. Serum tau protein levels in diffuse axonal injury model rats. Serum tau protein levels increased significantly as degree of diffuse axonal injury increased at one hour after injury (sham vs. mild, $P=0.024$, sham vs. severe, $P=0.016$, mild vs. severe, $P=0.018$ ). $P$ values were calculated using Mann-Whitney's U-test. Error bars indicate inter-quartile range. ${ }^{\star} P<0.05$. higher in rats subjected to focal brain injury compared to sham operated controls. The highest level was observed one hour after injury, compared to values at $6 \mathrm{~h}, 24 \mathrm{~h}, 48 \mathrm{~h}$, and $168 \mathrm{~h}$. The serum tau protein levels increased according to the severity of the injury (sham vs. mild, $P<0.001$; mild vs. severe, $P<0.001$ ), which was consistent with our results despite the difference in the injury model ${ }^{13}$. However, to the best of our knowledge, no study has demonstrated the relationship between the severity of DAI and serum tau protein level. By using the rat DAI model rat, we were able to demonstrate that the serum level of tau protein increases significantly and consistently according to the severity of DAI.

There are several limitations in this study. In Marmarou's study, the severity of traumatic brain injury of rats was differentiated by the height of the weight drop and confirmed according to the mortality after impact. Although we followed the same procedures for producing the models in this study, we did not evaluate the severity of DAI. Furthermore, we only evaluated serum tau protein level at a single time point of one hour from traumatic brain injury. However, setting multiple timepoints may have contributed to a more precise evaluation of the relationship between serum tau protein level and severity of DAI.

In conclusion, the serum levels of tau protein may be a useful biomarker for diagnosing and estimating the severity of DAI in the early phase.

\section{Data availability}

Underlying data

DRYAD: Serum levels of tau protein increase according to the severity of the injury in DAI rat model. https://doi.org/10.5061/ dryad.3r2280gc $9^{9}$.

Data are available under the terms of the Creative Commons Zero "No rights reserved" data waiver (CC0 1.0 Public domain dedication).
1. Gennarelli TA, Thibault LE, Adams JH, et al.: Diffuse axonal injury and traumatic coma in the primate. Ann Neurol. 1982; 12(6): 564-74. PubMed Abstract | Publisher Full Text

2. Chelly $\mathrm{H}$, Chaari $\mathrm{A}$, Daoud $\mathrm{E}$, et al.: Diffuse axonal injury in patients with head injuries: an epidemiologic and prognosis study of 124 cases. $J$ Trauma. 2011; 71(4): 838-46.

PubMed Abstract | Publisher Full Text

3. Buée L, Bussière T, Buée-Scherrer V, et al:: Tau protein isoforms, phosphorylation and role in neurodegenerative disorders. Brain Res Brain Res Rev. 2000; 33(1): 95-130.

PubMed Abstract | Publisher Full Text

4. Tomita K, Nakada TA, Oshima T, et al.: Tau protein as a diagnostic marker for diffuse axonal injury. PLOS One. 2019; 14(3): e0214381. PubMed Abstract | Publisher Full Text | Free Full Text

5. Shahim $\mathrm{P}$, Tegner $\mathrm{Y}$, Wilson $\mathrm{DH}$, et al.: Blood biomarkers for brain injury in concussed professional ice hockey players. JAMA Neurol. 2014; 71(6): 684-92. PubMed Abstract | Publisher Full Text

6. Rubenstein R, Chang B, Yue JK, et al:: Comparing Plasma Phospho Tau, Total Tau, and Phospho Tau-Total Tau Ratio as Acute and Chronic Traumatic Brain Injury Biomarkers. JAMA Neurol. 2017; 74(9): 1063-72. PubMed Abstract | Publisher Full Text | Free Full Text

7. Marmarou A, Foda MA, van den Brink W, et al:: A new model of diffuse brain injury in rats. Part I: Pathophysiology and biomechanics. J Neurosurg. 1994;
80(2): 291-300.

PubMed Abstract | Publisher Full Text

8. Gaertner DJ, Hallman TM, Hankenson FC, et al.: Anesthesia and Analgesia for Laboratory Rodents. $2^{\text {nd }}$ ed., Anesthesia and Analgesia in Laboratory Animals (London, UK: Academic Press, 2008). 239-97.

Publisher Full Text

9. Tomita K, Nakada T, Oshima T, et al:: Serum levels of tau protein increase according to the severity of the injury in DAI rat model, v2. Dryad. Dataset. 2020. http://www.doi.org/10.5061/dryad.3r2280gc9

10. Chabok SY, Moghadam AD, Saneei Z, et al.: Neuron-specific enolase and S100BB as outcome predictors in severe diffuse axonal injury. J Trauma Acute Care Surg. 2012; 72(6): 1654-7.

PubMed Abstract | Publisher Full Text

11. Pelinka LE, Kroepfl A, Leixnering M, et al:: GFAP versus $\mathbf{S 1 0 0 B}$ in serum after traumatic brain injury: relationship to brain damage and outcome. $J$ Neurotrauma. 2004; 21(11): 1553-61. PubMed Abstract | Publisher Full Text

12. Zurek J, Bartlova L, Fedora M: Hyperphosphorylated neurofilament NF-H as a predictor of mortality after brain injury in children. Brain Inj. 2011; 25(2): 221-6. PubMed Abstract | Publisher Full Text

13. Liliang PC, Liang CL, Lu K, et al.: Relationship between injury severity and serum tau protein levels in traumatic brain injured rats. Resuscitation. 2010; 81(9): 1205-8

PubMed Abstract | Publisher Full Text 


\section{Open Peer Review}

\section{Current Peer Review Status:}

\section{Version 1}

Reviewer Report 30 November 2020

https://doi.org/10.5256/f1000research.23261.r74639

C $\mathbf{2 0 2 0}$ Heslegrave A. This is an open access peer review report distributed under the terms of the Creative Commons Attribution License, which permits unrestricted use, distribution, and reproduction in any medium, provided the original work is properly cited.

\section{Amanda Heslegrave}

Department of Neurodegenerative Diseases, University College London, London, UK

This study aims to investigate whether serum tau could be a useful biomarker for estimating the severity of diffuse axonal injury in the early stages after trauma. The study uses a method to induce injury which depends on a weight dropped from a height to provide impact onto a helmet fixed to the rats head; two different heights were used.

The design of the experiment is simple and also the outcome was one serum tau measurement. The experiment assumes that the rats in each group receive the same injury - which is not unreasonable but is there a way to check this? Also the threshold for injury could have been tested by using more height conditions.

Overall the conclusions do not seem unreasonable; that tau is increased quickly in serum following neuronal injury.

Is the work clearly and accurately presented and does it cite the current literature? Yes

Is the study design appropriate and is the work technically sound?

Yes

Are sufficient details of methods and analysis provided to allow replication by others? Yes

If applicable, is the statistical analysis and its interpretation appropriate? Yes

Are all the source data underlying the results available to ensure full reproducibility? Yes 
Are the conclusions drawn adequately supported by the results?

Yes

Competing Interests: No competing interests were disclosed.

Reviewer Expertise: Biomarkers of neurodegenerative disease

I confirm that I have read this submission and believe that I have an appropriate level of expertise to confirm that it is of an acceptable scientific standard.

Reviewer Report 20 November 2020

https://doi.org/10.5256/f1000research.23261.r74640

(C) 2020 Olczak M. This is an open access peer review report distributed under the terms of the Creative Commons Attribution License, which permits unrestricted use, distribution, and reproduction in any medium, provided the original work is properly cited.

\section{Mieszko Olczak}

Department of Forensic Medicine, Medical University of Warsaw, Warsaw, Poland

The study evaluates the association between serum tau levels and the severity of brain injury in an animal model.

Methodology, statistical analysis, results, and discussion are done correctly. One of the drawbacks of the work is the small size of research groups. It should be assumed that the differences between animals within the research groups are minimal and the results are reproducible. I have no objections.

Is the work clearly and accurately presented and does it cite the current literature? Yes

Is the study design appropriate and is the work technically sound? Yes

Are sufficient details of methods and analysis provided to allow replication by others? Yes

If applicable, is the statistical analysis and its interpretation appropriate? Yes

Are all the source data underlying the results available to ensure full reproducibility? Yes

Are the conclusions drawn adequately supported by the results? Yes 
Competing Interests: No competing interests were disclosed.

Reviewer Expertise: Central nervous system, forensic medicine, trauma

I confirm that I have read this submission and believe that I have an appropriate level of expertise to confirm that it is of an acceptable scientific standard.

Reviewer Report 17 August 2020

https://doi.org/10.5256/f1000research.23261.r69132

(c) 2020 Koliatsos V. This is an open access peer review report distributed under the terms of the Creative Commons Attribution License, which permits unrestricted use, distribution, and reproduction in any medium, provided the original work is properly cited.

\section{Vassilis E Koliatsos}

Departments of Pathology, Neurology, and Psychiatry and Behavioral Sciences, Johns Hopkins University, Baltimore, MD, USA

This is a simple straightforward report on the serum levels of tau protein, measured by ELISA, in two different settings of the impact-acceleration model of diffuse traumatic brain injury (presumably causing two degrees of severity of diffuse axonal injury [DAI]). The advantage of having such data available is to show that we may have (emphasis is on may) a peripheral reporter of the severity of diffuse TBI and, potentially, DAI, using a model that is very appropriate for the task.

However, as the authors would be the first to acknowledge, this experiment uses only two degrees of severity of impact acceleration (IA) based on mechanical inputs without testing for severity of traumatic brain injury and certainly not severity of DAI by any of the available applicable measures, also without a time course for the observed changes that is essential for characterizing DAI. Therefore, the neuropathology of DAI has not been tested here and it would appear that the only part of the report where something like this could be mentioned is the Discussion-certainly not the title, where a more neutral term such as "severity of impact acceleration" would be more appropriate.

Also, with only two degrees of IA tested, the conditional "may" should be used throughout. We need more work before we can look at a definitive study linking peripheral tau protein levels to severity of diffuse traumatic brain injury and quite a bit more if we want to explore peripheral markers of DAI.

Is the work clearly and accurately presented and does it cite the current literature? Yes

Is the study design appropriate and is the work technically sound? Yes

Are sufficient details of methods and analysis provided to allow replication by others? 
Yes

If applicable, is the statistical analysis and its interpretation appropriate?

Partly

Are all the source data underlying the results available to ensure full reproducibility? Yes

Are the conclusions drawn adequately supported by the results? Partly

Competing Interests: No competing interests were disclosed.

Reviewer Expertise: Traumatic brain injury, neurodegenerative disease, neuropathology, axonopathy, axons, Wallerian degeneration, brain-behavior correlations

I confirm that I have read this submission and believe that I have an appropriate level of expertise to confirm that it is of an acceptable scientific standard, however I have significant reservations, as outlined above.

The benefits of publishing with F1000Research:

- Your article is published within days, with no editorial bias

- You can publish traditional articles, null/negative results, case reports, data notes and more

- The peer review process is transparent and collaborative

- Your article is indexed in PubMed after passing peer review

- Dedicated customer support at every stage

For pre-submission enquiries, contact research@f1000.com

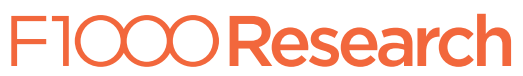

